\title{
25 Years of Criteria and Indicators for Sustainable Forest Management: How Intergovernmental C\&I Processes Have Made a Difference
}

\author{
Stefanie Linser ${ }^{1,2, *}$, Bernhard Wolfslehner ${ }^{1,2}$, Simon R. J. Bridge ${ }^{3}$, David Gritten ${ }^{4}$, \\ Steven Johnson ${ }^{5}$, Tim Payn ${ }^{6,7}{ }^{\circ}$, Kit Prins ${ }^{8}$, Rastislav Raši ${ }^{9}$ and Guy Robertson ${ }^{10}$ \\ 1 Institute of Forest, Environmental and Natural Resource Policy, Department of Economics and Social \\ Sciences, University of Natural Resources and Life Sciences, Vienna (BOKU), Vienna, 1180 Vienna, Austria \\ 2 European Forest Institute, Forest Policy Research Network, 1180 Vienna, Austria; \\ bernhard.wolfslehner@efi.int \\ 3 Natural Resources Canada-Canadian Forest Service, Ottawa, ON K1A 0E4, Canada; \\ simon.bridge@canada.ca \\ 4 RECOFTC-The Center for People and Forests, Bangkok 10903, Thailand; david.gritten@recoftc.org \\ 5 International Tropical Timber Organization (ITTO), International Organizations Center, \\ Yokohama 220-0012, Japan; johnson@itto.int \\ 6 Scion-New Zealand Forest Research Institute Limited, Rotorua 3010, New Zealand; \\ tim.payn@scionresearch.com \\ 7 Toi Ohomai Institute of Technology, Rotorua 3046, New Zealand \\ 8 Independent Forest Sector Consultant, 1227 Carouge, Switzerland; kit.prins@gmail.com \\ 9 Forest Europe Liaison Unit Bratislava, National Forest Centre, 96092 Zvolen, Slovakia; \\ rastislav.rasi@foresteurope.org \\ 10 U.S. Forest Service, Research and Development, Washington, DC 20250, USA; grobertson02@fs.fed.us \\ * Correspondence: stefanie.linser@boku.ac.at; Tel.: +43-1-47654-73222
}

Received: 3 August 2018; Accepted: 15 September 2018; Published: 18 September 2018

\begin{abstract}
Growing concern about forest degradation and loss, combined with the political impetus supplied by the Earth Summit in 1992, led to the establishment of eleven intergovernmental, regional, and international forest-related processes focused on the use of criteria and indicators (C\&I) for sustainable forest management (SFM). Up to 171 countries have participated in these processes to apply C\&I frameworks as a tool for data collection, monitoring, assessment, and reporting on SFM and on achieving various forest-related UN Sustainable Development Goals. Based on an expert survey and literature analysis we identify six interlinked impact domains of C\&I efforts: (1) enhanced discourse and understanding of SFM; (2) shaped and focused engagement of science in SFM; (3) improved monitoring and reporting on SFM to facilitate transparency and evidence-based decision-making; (4) strengthened forest management practices; (5) facilitated assessment of progress towards SFM goals; and (6) improved forest-related dialog and communication. We conclude that the 25-year history of C\&I work in forestry has had significant positive impacts, though challenges do remain for the implementation of C\&I and progress towards SFM. The work should be continued and carried over to other sectors to advance sustainability goals more broadly.
\end{abstract}

Keywords: criteria; indicators; C\&I; sustainable forest management; regional processes; international processes; intergovernmental processes; impacts 


\section{Introduction}

For more than 25 years, numerous actors have been involved in the development of criteria and indicators (C\&I) to conceptualize, monitor, assess, and report on sustainable forest management (SFM) at the international, regional, and national levels.

We use the definition adopted by the United Nations, which describes SFM as "a dynamic and evolving concept [that aims] to maintain and enhance the economic, social and environmental values of all types of forests, for the benefit of present and future generations" [1]. All the following considerations on C\&I are based on the widely applied definitions of FAO [2], whereby: "CRITERIA define the essential elements against which sustainability is assessed, with due consideration paid to the productive, protective and social roles of forests and forest ecosystems"; and "INDICATORS are parameters which can be measured and correspond to a particular criterion. They measure and help monitor the status and changes of forests in quantitative, qualitative and descriptive terms that reflect forest values as seen by those who defined each criterion".

C\&I are increasingly attractive to decision-makers and designers of decision-making processes, recognizing that processes utilizing C\&I are viewed as being efficient, consistent, transparent, scientific, and impartial [3]. C\&I are also commonly recognized as appropriate tools for defining, monitoring, reporting, and assessing progress towards SFM [4-14].

The most comprehensive public sets of C\&I for SFM have been developed in the forest sector. Based on the concepts of sustainable development and SFM, these C\&I integrate environmental, economic, social, and cultural values, extending well beyond the narrow consideration of the provision of wood products and making these sets unique in their holistic approach to SFM [15].

\section{Scope and Objectives of the Paper}

In this paper, we identify the actual and potential impacts of public C\&I sets used by the various intergovernmental forest-related regional and international C\&I processes, and we consider the ways these impacts have been manifested.

After 25 years of experience [15], C\&I for SFM are becoming increasingly important in the development of a knowledge-based society, including informed policy making. Indicators are frequently required in global processes, such as that involved in the SDGs [16]. Indicators can cut across sectors through, for example, bioeconomy [14]. On the other hand, indicators often require significant resources for data collection and monitoring, and efficiency and effectiveness are therefore crucial. This paper summarizes and reflects on the impacts of C\&I development within processes on C\&I for SFM, and it discusses the challenges involved in the further implementation of C\&I and progress towards SFM.

\section{Materials and Methods}

An international expert workshop held in Ottawa, Canada, in May 2016 on strengthening collaboration on C\&I to promote and demonstrate SFM [17] concluded, among other things, that there is an urgent need for information on the various impacts of the intergovernmental, regional, and international C\&I for SFM. The work in developing this paper was conducted within the IUFRO Working Party 9.01.05 on Research and Development of Indicators for Sustainable Forest Management. All authors are active in this working party and are representatives of, or insiders in, the regional or international C\&I processes that apply to specific regions or types of forests like boreal, temperate, tropical, dry forests, or low-forest-cover. Thus, we always refer to regional and international processes. These C\&I processes are:

- $\quad$ the International Tropical Timber Organization (ITTO)'s C\&I for the sustainable management of tropical forests;

- the Pan-European Forest Process on C\&I for SFM under the Ministerial Conference for the Protection of Forests in Europe, known also as FOREST EUROPE; 
- the Montréal Process on C\&I for the conservation and sustainable management of temperate and boreal forests;

- the Amazon Cooperation Treaty Organization (ACTO) Tarapoto Process on C\&I for the sustainability of Amazon forests, recently renamed the "process of harmonized C\&I of ITTO-ACTO (Tarapoto) for the sustainability of the Amazon forests";

- the Association of Southeast Asian Nations (ASEAN) C\&I for the sustainable management of tropical forests in Southeast Asia;

- the Low Forest Cover Countries Process, also known as the Tehran Process;

- the African Timber Organization (ATO)/ITTO C\&I process;

- the Dry-Zone Africa Process on C\&I for the sustainable management of dry-zone forests in sub-Saharan countries;

- the Near East and North Africa (NENA) Process on C\&I for sustainable management of dry-zone forests;

- $\quad$ the Lepaterique Process of Central America on C\&I for SFM; and

- the Dry Forests in Asia Regional Initiative for the development and implementation of national-level C\&I for the sustainable management of dry forests in Asia (also known as the India-Bhopal Process).

The various international and regional C\&I processes are implemented in different ways and settings [15]. This partly explains why a single method or framework for assessing their impacts does not exist. In order to identify and assess such impacts, therefore, this paper relies primarily upon literature review and consultation with experts from the various regional and international C\&I processes.

In the literature review, we analyzed 99 relevant grey-literature references (books, technical reports, and publications by international organizations like FAO, ITTO, and the EFI) and 59 primary literature references (articles in peer-reviewed academic journals). Online database searches were conducted in the Scopus database and Google Scholar to find appropriate literature in the time span from the Earth Summit in 1992 until May 2018. We used several search terms, as well as combinations thereof, to ensure that the literature review was comprehensive. The search terms were: "C\&I for SFM"; "criteria and indicators for sustainable forest management"; and "forest-related indicators".

Further empirical information is based on the expert inputs of the authors and a survey conducted in late 2016 in which a paper questionnaire based on [18] was sent to the secretariats of the regional and international C\&I for SFM processes and to representatives of or contributors to such processes, including the authors of this paper. We used a mixed procedure with standardized questions (closed questions and fixed response options) and non-standardized questions (open questions and open answers) according to [19] to receive comparable data and complementary information. The questionnaire also enabled respondents to go into detail in their areas of expertise. It addressed the specific process and C\&I set (cf. [15]) and gathered information on the purpose, usage, achievements, and impacts of the regional and international indicator sets, such as harmonization, common understanding of concepts, terms, definitions, consideration of research efforts, and impacts. The latter is in the focus of our paper. Representatives and experts from 8 of the 11 regional and international processes responded to the questionnaire. Information on the three inactive C\&I processes (ATO/ITTO, Lepaterique, Dry-Zone Africa) is based on technical reports and reports of conferences and workshops conducted during their active phases.

Based on an empirical analysis of the relevant literature and expert inputs, we identified various preliminary "impact domains" for C\&I. The assessment of these impact domains starts from the hypothesis that regional and international C\&I for SFM are structures for information management on forests and forestry, which, if well developed and applied, lead to greater comprehension and implementation of SFM. 
The preliminary results of the analysis were presented at the IUFRO Anniversary Congress in September 2017 in Freiburg, Germany. Based on the ensuing discussion, the following final six impact domains were determined: (1) the discourse of SFM; (2) science applications; (3) monitoring and reporting on SFM; (4) SFM practices; (5) assessment of progress towards SFM; and (6) forest-related dialogue and communication. These six impact domains form the basis of the overall evaluation of C\&I impacts outlined in this paper.

\section{Results}

\subsection{Impact on the Discourse of SFM}

The understanding of sustainability and the responsibility to maintain forests has changed considerably in recent decades, especially since the UN Conference on Environment and Development (UNCED) in 1992 and initiation of the C\&I for SFM processes mainly based on a call for the development of C\&I for sustainable development at multiple levels made in Chapter 40.4 of Agenda 21 ("Indicators of sustainable development need to be developed to provide solid bases for decision-making at all levels and to contribute to a self-regulating sustainability of integrated environmental and development systems."), which was agreed at UNCED [20]. The guiding principle of sustainable development, although widely accepted, has however, a noteworthy weakness: the difficulty of measuring sustainability. Nevertheless, it must be recognized that the C\&I processes considered in this report are part of a long-standing development of forest monitoring and management techniques stretching back for centuries. While the challenges in measurement have increased as we have more fully recognized the complexities of forest ecosystems and the values associated with them, these challenges are not new in a fundamental sense.

C\&I for SFM have evolved as a commonly agreed instrument for monitoring, reporting, articulating, and defining expectations, including targets [21], and in developing managerial methods, best practices [22], and performance elements of SFM. C\&I for SFM have then been used in monitoring and evaluating progress towards those expectations and targets $[8,13,23,24]$. Thus, C\&I provide a tacit definition of SFM, and they contributed to a paradigm shift in forestry away from a focus on sustained timber yield towards a broader, more holistic view of forest management [15].

According to our analysis, the various sets of C\&I for SFM have influenced the discourse of SFM particularly by:

- facilitating societal consensus on how forests should be managed and what a society wants from its forests [25];

- $\quad$ making general concepts of sustainable development and abstract concepts like socio-economic benefits more concrete and operational by specifying what should actually be measured [4];

- $\quad$ supporting new modes of governance in national forest policy-making by shaping debate on SFM at the national level $[26,27]$.

- $\quad$ increasing political commitment to SFM by providing a reference framework for SFM-related policies, enhancing the accountability and transparency of policy-making, and better integrating policy-making with evidence-based forest reporting. Today, the concept of SFM, as characterized by C\&I for SFM, is embodied in many national forest programmes and forest-related planning documents $[4,5,26]$; and

- $\quad$ facilitating common understanding of SFM-related concepts, terms, and definitions [28].

\subsection{Impact on Science Applications}

C\&I in general are based on scientific foundations for determining sustainability of forest management, and provide a tool covering different dimensions of SFM. Grainger [29], Pokorny and Adams [30], and Wijewardana [31] give comprehensive overviews of scientific C\&I applications. The scientific development of C\&I led to a more consistent approach in defining and 
monitoring SFM worldwide, from the political to the management planning level [5]. More specifically, the regional and international C\&I processes and the related sets have inspired scientific advancement in monitoring methodologies as well as the harmonization of monitoring systems $[5,9,17,32]$. Literature suggests that the international scientific discourse on SFM has had a significant influence on the further development and uptake of C\&I at different implementation levels. The number of scientific publications addressing issues related to SFM is relatively high. Nearly 11,000 scientific publications published between UNCED in 1992 and 9 May 2018 and listed in the Scopus database, include the terms "sustainable", "forest", and "management" in title, abstract or keywords. About $10 \%$ of these (1156 Scopus entries) also address C\&I, and 59 papers directly address regional and international C\&I processes and indicators for SFM. The activities of the forest-related C\&I processes have considerably shaped the scientific approach towards SFM [5] (and vice-versa because C\&I revision processes have taken scientific results into account). This has occurred in parallel to the involvement of scientists in public and policy level discussions on the management of forests, including the UNFCCC, though communication barriers, based on the cultural differences between the groups, still often remain [33].

Some of the C\&I processes have produced a considerable volume of outputs: for example, ITTO pioneered the development of C\&I for SFM in the early 1990s and has provided leadership in their review and improvement, leading to more than 20 publications on C\&I for SFM. In its role as initiator and facilitator of several regional processes, FAO has provided and published 86 C\&I-related reports and workshop proceedings. Projects dealing with the development, implementation, or analysis of C\&I have received strong support from international donors over the past 25 years $[4,34,35]$.

The need for adequate national data is a large and common issue across countries (see Section 3.3) and has had a significant effect in shaping the identification, planning, and managing of C\&I-related research projects. In Canada, for example, the C\&I framework was used to identify research gaps that were then communicated to the underlying national and international C\&I processes [36]. In New Zealand, the Montréal Process C\&I were used to structure a synthesis of stakeholder preferences and values for the country's forest sector to inform the design of the national SFM research programme $[37,38]$. Capacity development and the inclusion of scientists in C\&I process negotiations have also been important achievements, as well as the inclusion of C\&I-related sessions at international congresses (e.g., the World Forestry Congress and the IUFRO World Congress).

More generally, the C\&I processes have helped to systematize and rationalize data development and analysis around SFM. By presenting each indicator or criteria as what is essentially a discreet hypothesis test regarding sustainability, sustainability C\&I serve to focus analysis, though the actual approach to these tests has been quite variable [39].

However, on a more systemic level there is still room for development. Scientific sustainability assessments in forestry appears at best to be a collection of different dimensions of SFM, but the interactions between the ecological and socio-economic dimensions are not covered systematically (e.g., [40]). This leads to questions regarding scientific progress and the uptake of C\&I as multi-dimensional tool for supporting decision-making at the policy level, as they were originally considered to be.

\subsection{Impact on Monitoring and Reporting of SFM}

FAO has been collecting forest-related data and information in its world forest inventories and FRAs since the late 1940s, and it has been working to strengthen data coverage and comparability. The need for comprehensive monitoring and reporting on the state of the forests was additionally stimulated by the non-legally binding authoritative statement of principles for a global consensus on the management, conservation, and sustainable development of all type of forests [41]; previously, the focus had been on forest area and wood stocks, with little consideration of biodiversity, socio-economic aspects, or forest health and vitality. Collaboration and cooperation to harmonize data among the C\&I processes has been a major issue in the past 25 years because country data are not easily 
comparable in the compilations of FAO or the reports of the C\&I processes [42,43]. There has been a common intention to improve comparability between the various C\&I for SFM processes, with due consideration for their particular environmental and socio-economic contexts. Moreover, because natural resources are not confined by administrative boundaries, transboundary monitoring is often required. Various international expert meetings since the 1990s, including the "Kotka" meetings to guide the FRAs, e.g., [32,44-48], have attempted to define and harmonize terminology, monitoring and reporting to facilitate comparisons between countries. C\&I frameworks were used as a basis for the UN's "seven thematic elements of SFM" [1] and subsequently by FAO in its FRAs; they are, therefore, applicable to all countries to a certain extent. Nevertheless, not all C\&I processes attach as much importance to data comparability as FAO does in compiling its FRAs, considering it more important to develop national, regional or international approaches to specific problems.

Our analysis finds that the regional and international C\&I processes and sets have:

- Shaped, improved, and streamlined national reporting. C\&I for SFM have been used as a framework and basis for national monitoring applications and reporting on SFM. Progress and adaptation of C\&I-based monitoring instruments have been observed in many countries, and data collection has been streamlined. This is particularly important for the long-term development of national inventory systems, which have steadily improved to cover all aspects of SFM, as identified in C\&I sets. The C\&I sets have helped improve data availability, validity, and quality in areas not previously covered in forest-sector statistics, which generally focused on resource inventory and lacked social, environmental, economic, and cultural aspects [4,5,21,26,46,49].

- Contributed conceptually and practically to improvements in the comparability of time series of forest-related information within and between regions by supporting a common reporting framework known as the Collaborative Forest Resources Questionnaire (CFRQ) [5,26,49]. Since the beginning of FOREST EUROPE reporting on C\&I, for example, efforts have been made to reduce the reporting burden and to enhance the coordination of data collection, with informal coordination between the UN Economic Commission for Europe (UNECE)/FAO process and regional and international C\&I processes. FAO, the UNECE, FOREST EUROPE, ITTO, the Montréal Process, and the Observatory of Central African Forests all cooperated to harmonize data collection for the FRA 2015, the forthcoming FRA 2020 and the reports of various regional and international C\&I processes. In 2018, ACTO started negotiating a memorandum of understanding with FAO that includes its support to also use the CFRQ to collect forest information for the Amazon region.

- Provided information of international relevance. C\&I-based data collection has made forest-related data available to broader policy processes [5,50]. It has also contributed to reporting and assessment for a range of global policy goals, objectives, and targets, including the Non-Legally Binding Instrument (NLBI)'s Global Objectives on Forests, the UN Strategic Plan for Forests, and the CBD's Aichi Targets.

- Provided the basis for the proposal and acceptance of indicators for reporting on forest-related SDG targets 15.1 and 15.2 [16]. The whole SDG indicator set contains around 20 indicators that may be linked to forests in one way or another and two that specifically refer to forests: 15.1.1 'trends in forest cover' and 15.2.1 'area of forest under sustainable forest management', the latter of which includes five sub-indicators [16] which are included in most of the regional and international indicator sets.

- Provided a pool for the selection of a global core set of forest-related indicators [18,51], comprising a limited number of indicators necessary for monitoring progress towards international goals, objectives, and targets. The intention is to focus and prioritize monitoring and reporting efforts and avoid duplication. Key indicators as an information base for decision-makers and the broad public were developed recently as part of the Tarapoto process [52] and are under development in the FOREST EUROPE Process [9,53].

- Reduced multiple reporting burdens on emerging related issues by including recognized indicators from other international processes in their regional and international CEI sets. The ITTO, FOREST EUROPE, and Tehran Process include, for instance, indicators relevant to the CBD (e.g., biodiversity 
conservation measures in natural production forests, common forest bird species, and forest fragmentation), UNCCD (e.g., trends in forest land degradation, degraded forests, and landscape restored), the Convention on International Trade in Endangered Species of Wild Fauna and Flora (CITES) (e.g., tree species in each of the CITES appendices) and the UNFCCC (e.g., changes in carbon stock in forest biomass, forest soils, and harvested wood products).

Enhanced evidence-based decision-making. From the local to the global level, C\&I have directly or indirectly influenced the modalities of decision-making: many countries perform regular public-policy evaluations and use social, economic, and environmental indicators, including forest-related indicators, for this purpose [4,53-55].

\subsection{Impact on Sustainable Forest Management Practices}

In addition to regional and international C\&I development and national implementation, the C\&I processes have fostered a shift from a focus on sustained yield (mostly of wood) towards a broader and more holistic approach to SFM. In regard to incentivizing a shift towards sustainable practices, particularly at the local level, our analysis shows that the C\&I sets have contributed to:

- The integration of stakeholder participation in forest management to ensure that a broad range of values are considered $[17,24,28,32,56]$. This is despite concerns that C\&I processes are top-down and overly complex and sideline the knowledge and experience of forest communities, including Indigenous Peoples, in the developing world [57].

- Improving access to resource use rights. C\&I have been used as references for national governments in providing a transparent system and rule base for granting use rights, including means for controlling and verification [22,35]. There is concern that, in some developing countries, a lack of local knowledge and resources to implement C\&I may constrain the rights of rural communities because local government staff lack the knowledge and resources to support efforts to adhere to the C\&I, making legal forest management prohibitively expensive [57].

- Better access to funding. By providing an internationally agreed and comprehensive conceptual framework, C\&I help to justify requests to mobilize funding or investments for forest products and ecosystem services that emphasise SFM [4,22,34,35].

- Compliance control of forest management. C\&I have been used to audit the forest management regimes of timber concessionaires [22,34,35,58,59].

- The development of forest certification. The concept of C\&I served as a stepping stone for the development of forest certification schemes, which are market-driven instruments designed to improve market access for forest products that have produced according to good forest practices $[4,22,35,60]$. The importance of forest certification varies significantly across the world [15,61],

- Improve access to markets. C\&I have been used in community forestry to increase access to local and international markets $[22,35]$. However, there is concern that smallholders and rural communities in developing countries have limited capacity to meet the specifications of C\&I (e.g., in certification schemes), with the effect of constraining market access [61].

\subsection{Impact on the Assessment of Progress towards SFM}

Decision-making as an adaptive process requires the assessment of the state of forests and the progress being made towards SFM goals and targets. In this regard, the C\&I sets developed by the regional and international processes impacted on:

- The first steps in the review of trends and benchmarks between countries. Time series data for some SFM indicators are available from the early 1950s (or before), and coverage has improved steadily, partly under the influence of C\&I since the 1990s. In Europe, assessment prototypes were presented in "State of Europe's Forests" reports in 2007 and 2011, and these will be subject to further 
revisions and development $[8,23,62]$. ITTO's "Status of Tropical Forest Management" reports published in 2006 and 2011 [63,64] were carried out explicitly to assess progress towards SFM in the Organization's tropical member countries using the ITTO C\&I reporting framework. A third assessment is planned before 2020;

- The development of the UNECE pilot project, "System for the Evaluation of the Management of Forests" (SEMAFOR). SEMAFOR is based on the assessment of the sustainability of forest management in 20 European countries on the basis of the pan-European C\&I for SFM, setting common thresholds, leading to a dialogue with national correspondents on threats to SFM and the policy measures being put in place to address identified issues [13];

- Various forest-related global or regional goals, such as the SDGs (e.g., 15.2.1), the Global Forest Goals and their associated targets, and the Goals for European Forests and the European 2020 Targets for Forests. These have been set mostly independently of C\&I but in related processes $[4,8]$. Further work-and close cooperation between the policy and technical levels-is required to use the data and insights developed in the C\&I processes to monitor progress towards officially agreed goals.

\subsection{Impact on Dialogue and Communication}

In general, indicators have broadly been acknowledged over the past 25 years as a means of presenting knowledge in objective, focused and comparable ways for policy-makers, stakeholders, and the interested public $[5,7,65]$. Jointly agreed sets of indicators facilitate information exchange and decision-making on SFM and related issues. Indicators thus have the potential to serve requests of policy-makers to "get the politics out of policy making" [27] by focusing on indicator-based decision-making and enabling the use of comparable forest-related information to guide policy-making [66] and the condensed, comprehensible communication of knowledge to policy and the broad public [67-69]. On the other hand, SFM widely remains a political and therefore often meandering process. Nonetheless, the explicit presentation of factual information within a C\&I framework can serve as an evidence base for political assertions and empower marginalized participants in policy debates even so it is yet far from practice. In our analysis, we found that the regional and international C\&I processes and sets have resulted in:

- Increased awareness and understanding of SFM, at least in the forest sector and among forest stakeholders and many of those interested in forestry issues $[4,5,26,28,65,70]$.

- Improved communication within the forest sector in terms of common language, mind-setting, and streamlining the forestry debate [5,70].

- Facilitated deliberations and consultations between policy-makers and stakeholders, thus promoting stronger stakeholder participation and improved evidence-based decision-making in forest-related policy processes $[5,28]$. Some of the literature, on the other hand, points out that these processes have limited participation of forest communities in developing nations [57].

- Raised the attention and interest of other sectors in forest-related information, in particular energy, climate change, and biodiversity [5].

- Enabled the broader understanding and use of forest-related information in national, regional, and international evidence-based policy-making $[5,26]$ and in modern knowledge tools for global governance [27].

The above results are summarized in Table 1 , and the interactions of the six impact domains are displayed in Figure 1. In this manner we show that impact domains have multiple links to some or all other domains and that the indicators are particularly impacting on dialogue and communication. 
Table 1. Summary of the major impacts of intergovernmental, regional, and international C\&I processes and their respective sets.

\begin{tabular}{|c|c|c|c|c|c|}
\hline \multicolumn{6}{|c|}{ Impacts on ... } \\
\hline Discourse of SFM & Science Applications & $\begin{array}{l}\text { Monitoring and Reporting } \\
\text { on SFM }\end{array}$ & $\begin{array}{l}\text { Sustainable Forest } \\
\text { Management Practices }\end{array}$ & $\begin{array}{l}\text { Assessment of Progress } \\
\text { towards SFM }\end{array}$ & $\begin{array}{l}\text { Forest-Related Dialogue } \\
\text { and Communication }\end{array}$ \\
\hline $\begin{array}{l}\text { Facilitated societal consensus } \\
\text { building regarding } \\
\text { forest management }\end{array}$ & $\begin{array}{l}\text { Provided a framework to } \\
\text { guide research on SFM }\end{array}$ & $\begin{array}{l}\text { Shaped, improved, } \\
\text { and streamlined } \\
\text { national reporting }\end{array}$ & $\begin{array}{l}\text { Fostered a shift from } \\
\text { sustained yield to more } \\
\text { holistic SFM practices }\end{array}$ & $\begin{array}{l}\text { Facilitated efforts to } \\
\text { review differences in } \\
\text { trends between countries }\end{array}$ & $\begin{array}{l}\text { Increased awareness and } \\
\text { understanding of SFM }\end{array}$ \\
\hline $\begin{array}{l}\text { Made abstract concepts like } \\
\text { socio-economic benefits } \\
\text { more concrete }\end{array}$ & $\begin{array}{l}\text { Inspired new areas } \\
\text { of research }\end{array}$ & $\begin{array}{l}\text { Contributed to improve the } \\
\text { comparability of time series } \\
\text { and of information between } \\
\text { the various regions }\end{array}$ & $\begin{array}{l}\text { Increased stakeholder } \\
\text { participation in } \\
\text { SFM processes }\end{array}$ & $\begin{array}{l}\text { Fostered innovative } \\
\text { regional assessment } \\
\text { methods (e.g., SEMAFOR) }\end{array}$ & $\begin{array}{l}\text { Improved communication } \\
\text { within the forest sector }\end{array}$ \\
\hline $\begin{array}{l}\text { Supported new modes of } \\
\text { governance in national forest } \\
\text { policy-making }\end{array}$ & $\begin{array}{l}\text { Encouraged funding of C\&I } \\
\text { related research projects }\end{array}$ & $\begin{array}{l}\text { Aligned global forest } \\
\text { reporting with national data } \\
\text { collection systems }\end{array}$ & $\begin{array}{l}\text { Enabled better access to } \\
\text { resource use rights }\end{array}$ & $\begin{array}{l}\text { Contributed to assessment } \\
\text { approaches for a variety } \\
\text { of forest-related global or } \\
\text { regional goals }\end{array}$ & $\begin{array}{l}\text { Facilitated deliberations } \\
\text { and consultations } \\
\text { between policy makers } \\
\text { and stakeholders }\end{array}$ \\
\hline $\begin{array}{l}\text { Increased the political } \\
\text { commitment to agree on and } \\
\text { support SFM }\end{array}$ & $\begin{array}{l}\text { Supported engagement of } \\
\text { scientists in SFM policy } \\
\text { discussions and negotiations }\end{array}$ & $\begin{array}{l}\text { Provided information of } \\
\text { international relevance to } \\
\text { high-level policy processes }\end{array}$ & $\begin{array}{l}\text { Mobilized investment in new } \\
\text { forest products and } \\
\text { ecosystem services }\end{array}$ & & $\begin{array}{l}\text { Raised attention and } \\
\text { interest in forest-related } \\
\text { information of } \\
\text { other sectors }\end{array}$ \\
\hline \multirow[t]{4}{*}{$\begin{array}{l}\text { Facilitated the common } \\
\text { understanding of related } \\
\text { concepts, terms and definitions }\end{array}$} & $\begin{array}{l}\text { Provided an organising } \\
\text { structure for scientific events, } \\
\text { conferences and } \\
\text { international congresses }\end{array}$ & $\begin{array}{l}\text { Provided indicators for the } \\
\text { reporting of the forest-related } \\
\text { SDG targets }\end{array}$ & $\begin{array}{l}\text { Aided control of compliance } \\
\text { with forest } \\
\text { management requirements }\end{array}$ & & $\begin{array}{l}\text { Broadened understanding } \\
\text { of forest related } \\
\text { information for } \\
\text { evidence-based } \\
\text { policy-making }\end{array}$ \\
\hline & & $\begin{array}{l}\text { Provided a pool for the } \\
\text { selection of a global core set } \\
\text { of forest related indicators }\end{array}$ & $\begin{array}{l}\text { Fostered development of } \\
\text { forest certification }\end{array}$ & & $\begin{array}{l}\text { Provided modern } \\
\text { knowledge tools for } \\
\text { global governance }\end{array}$ \\
\hline & & $\begin{array}{l}\text { Reduced multiple } \\
\text { reporting burdens }\end{array}$ & $\begin{array}{l}\text { Improved access to markets } \\
\text { for forest products from } \\
\text { sustainable sources }\end{array}$ & & \\
\hline & & $\begin{array}{l}\text { Enhanced evidence-based } \\
\text { decision-making }\end{array}$ & & & \\
\hline
\end{tabular}




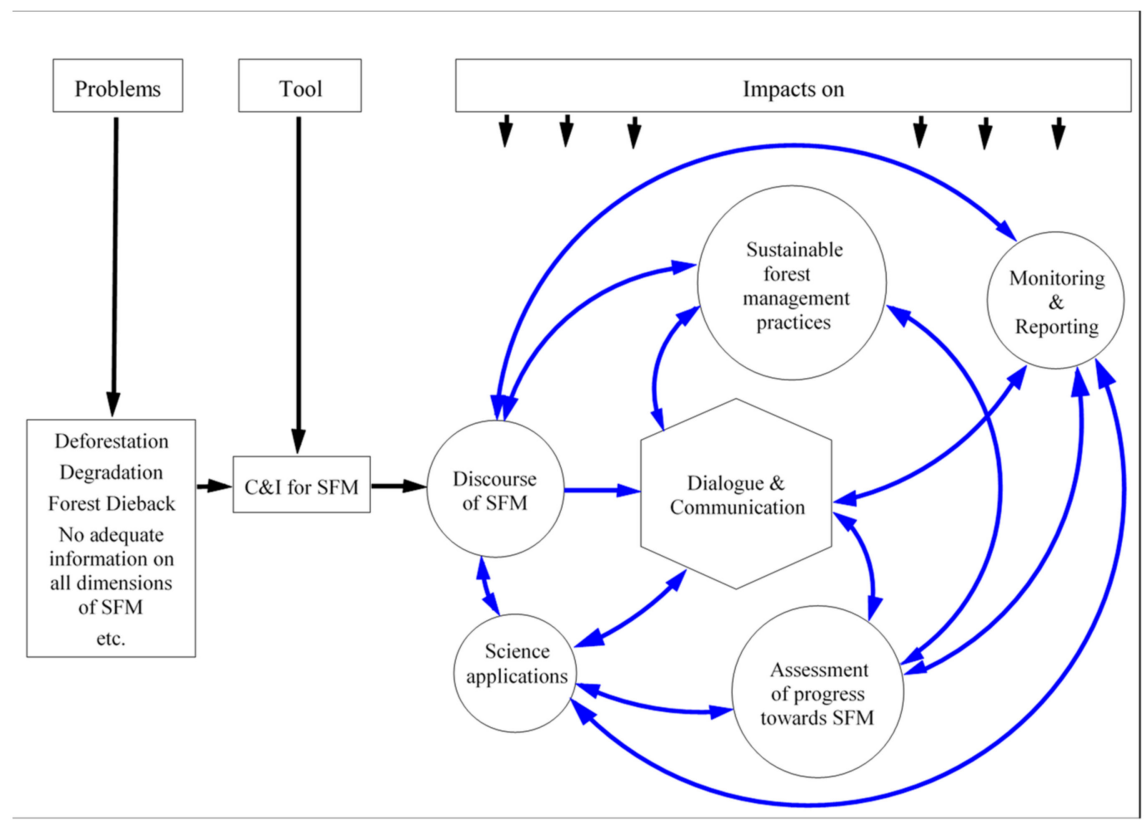

Figure 1. Linkages between the various impact domains of regional and international processes and their C\&I sets.

\section{Discussion}

We have identified six impact domains of regional and international C\&I processes and their respective sets of C\&I for SFM. These are closely interlinked (Figure 1), particularly strengthening the impacts of C\&I on dialogue and communication. These impacts are further discussed in this section.

\subsection{Impact on the Discourse of SFM}

Securing agreement on the definition and components of SFM has been a difficult task, both nationally and internationally [71]. Despite remarkable achievements in monitoring and assessing SFM using quantitative and qualitative indicators, some components of SFM are inherently hard to measure. The role of SFM in the provision of ecosystem services is a notable example of this [72]. In addition, the discourse on SFM has focused increasingly on social and cultural aspects in the past decade. Various expert working groups (e.g., that of FOREST EUROPE on ecosystem services [73]), projects and studies on recreation, well-being, and cultural values have helped build knowledge bases. Nevertheless, the comparability of indicators at the global or regional scale remains limited due to the heterogeneity of measures at lower spatial scales, thus limiting the potential for generalization of such aspects in the SFM discourse. Examples of how C\&I for SFM have impacted the SFM discourse for the consumers of wood products include the application of the pan-European C\&I for SFM in the Programme for the Endorsement of Forest Certification (PEFC) [74] and the use of the Montréal Process C\&I structure to inform the development of both Australia's and New Zealand's PEFC-endorsed forestry standards [75].

\subsection{Impact on Science Applications}

In the temperate zone, and in Europe in particular, forest science has a nearly 300-year history of development and broad application based on evolving concepts of SFM [25,76,77]. The C\&I concept has influenced SFM policy implementation, the scientific grounding of national C\&I processes, decision support in SFM, and procedures for implementing SFM, especially in terms of participation and sustainable development frameworks [5,35]. Rametsteiner et al. [78] scrutinized the relationship of policy-makers and experts in a C\&I developing process, highlighting the norm creation dimension of such endeavors. There are numerous and increasing C\&I-related scientific publications (cf. Section 3.2); 
in some cases, however, research outcomes have not found their way to potential users due to various economic and political factors that make practical implementation difficult, but also due to a disconnect, in communication terms, between scientists and foresters [33]. C\&I development and revision processes are driven mainly by the interests of participating stakeholders, who may have insufficient understanding of the practical relevance of scientific results [24], and this can lead to the partial disregard of scientific methods and approaches. The regional and international sets of C\&I for SFM are the result of stakeholder negotiations in broad-based, participatory, and democratic processes $[24,25,79]$, rather than integrated scientific systems based on, for example, a systems approach to characterizing ecosystem components. Arguably, more complex systems approaches to C\&I-in which science-based approaches connect SFM goals, objectives, actions, and outcomes in a stringent framework-have failed to reach the policy level [5,29]. Overall, while C\&I appear to have shaped SFM discourse and methodology development on monitoring and data collection, they still are lacking to provide answers to whether or not, and to which level, SFM is being achieved $[5,13]$. The highly political dimension of these questions could build the actual barrier between the scientific and political domain, and the policy aspect remains dominant over further scientific advances in the field of sustainability assessment of forest management.

\subsection{Impact on Monitoring and Reporting of SFM}

\subsubsection{Quantitative Information}

The various regional sets of C\&I for SFM reflect regional specificities, regarding, for example, forest type, maintenance of forest cover, reforestation/afforestation, indigenous rights, wellbeing, recreation, and emphasis on socio-economic or more ecological aspects. This makes it difficult to compare the regional and international sets of C\&I for SFM.

To enable comparisons of data measured at the national level, further harmonization is needed between the various sets of C\&I for SFM. The collection of large amounts of data often imposes considerable burdens on agencies, which, in many countries, are under financial pressure. National forest inventories-the major but by no means the only means for generating data for forest-related indicators-often need additional funds to expand or improve data, especially for measuring new indicators developed in C\&I for SFM processes. Support is also often requested to build capacities through education and training to implement and further develop global, regional, or national C\&I [55]. At least some countries in most regions have weak forest information infrastructure, meaning that even core data (e.g., forest area) are out of date, have no error estimates, are based on partial information, or are unavailable. Such countries are often those with the most urgent forest-sector problems [55]. These countries would benefit from efforts to strengthen institutions to provide at least the minimum information needed to properly monitor the implementation of SFM and related policy decisions.

Online-based tools are increasingly applied to simplify the reporting and analysis of C\&I-based data and the generation of periodic synthesis reports on SFM. Such tools enable efficiencies in data collection and information supply, with many of the data usable for multiple reporting requirements [35]. The guiding principle of "collect data once and use it many times" was a motivation for the revision of the ASEAN C\&I for SFM in 2017, with officials emphasizing the workload involved in collecting data for the various sets of C\&I [80].

The FRA is the main source of information on the state of forests globally, and FAO has been working to improve comparability among countries for about 70 years. The multi-agency CFRQ is the fruitful outcome of a joint commitment of FAO, the UNECE and some C\&I processes and an important step forward in reducing reporting burdens and improving data consistency. In a survey now underway (March-October 2018) [81], the CFRQ is completely integrated into the FRA questionnaire to avoid double reporting; thus, data collected, validated, and processed through the CFRQ can be shared with partners, including three regional C\&I processes. Focusing on quantitative indicators and 
on the most important and feasible indicators, the CFRQ covers about $40 \%$ of the FOREST EUROPE indicators, $30 \%$ of the ITTO indicators, and $25 \%$ of the Montréal Process indicators; through it, data are requested from 104 countries, representing $88 \%$ of the world's forests. In most cases, the requested data requested address essential core parameters such as forest area and growing stock. Nevertheless, it also addresses some increasingly important aspects not covered in some of the participating regional and international processes (e.g., on woody invasive species).

In cases where governments are challenged to invest more in forest monitoring and data collection, technologies such as remote sensing can help in generating data that previously were too expensive or technically impossible to collect. Continued innovation and meaningful investment in data collection and reporting mechanisms are required to further enhance harmonized monitoring and reporting on SFM. The weakest indicators are those that are conceptually weak (e.g., some of those addressing cultural aspects or ecosystem services), or which are outside the 'comfort zone' of forest inventory staff, such as those addressing non-wood forest products or economic or recreation-related aspects. Technologies such as remote sensing may not be very helpful for such less well-developed indicators. It is important to ensure that indicators are developed in collaborative and coherent ways, using new technologies where possible to maximize efficiency.

A number of global forest-related policy goals, objectives and targets, as well as recent trends in climate change and bioenergy, require information on aspects of SFM for which existing indicators, mechanisms and data are weak, particularly on socio-economic and qualitative governance aspects. These need further development. The use of a small number of streamlined indicators able to meet the reporting needs of multiple goals and processes (e.g., those of the UNFCCC, UNCCD, $\mathrm{CBD}$, and SDGs) is an effective strategy for enhancing common understanding, information sharing, and efficiency. Using globally agreed indicators, data, and reporting mechanisms (such as the FRA, CFRQ, national reports to UN bodies, and the global core set of forest-related indicators) is highly cost-effective, especially if these are integrated in national data collection and reporting schemes. Harmonizing reporting also helps to leverage limited resources to address data challenges.

Knowing the characteristics of the forest sector and how it is changing is of only minor value unless the information is shared through public reporting and brought to the notice of decision-makers. Nevertheless, not all countries participating in regional or international C\&I processes have used the relevant sets of C\&I for SFM in their reporting. An analysis of the country reports for the 2015 FRA, for example, showed that 86 countries provided C\&I-based reports, together accounting for $77 \%$ of the global forest area. These reports covered almost all the forest area in high, upper-middle, and lower-middle income countries; low-income countries, on the other hand, rarely used C\&I in their reporting [42,55].

\subsubsection{Qualitative Information}

Most forest C\&I sets include 'qualitative' indicators, which elicit information on laws, policies and institutions, thus drawing attention to the policy tools as well as to the physical outcomes. Often countries find it relatively straightforward to provide this information: the challenge is to analyze it and make a synthesis of non-comparable, non-numerical information. This process often occurs through synthetic or narrative analysis, and it points to the fact that, while many important aspects of SFM cannot always be addressed in quantitative fashion, they must nonetheless be considered [82]. However, the information provided by countries on their policies, institutions and instruments for SFM is often problematic in their analyses and narrative approaches [83].

Qualitative indicators are equally represented in all regional and international processes [15] but, in most sets, there is no connection between quantitative and qualitative indicators [36,52,84-87]. The most recent (2015) revision of the pan-European C\&I for SFM, however, attempted to link the quantitative and qualitative indicators by aligning policy information under each criterion, alongside a separate subset of qualitative indicators on the overarching policy framework [76]. 


\subsection{Impact on Sustainable Forest Management Practices}

ITTO's work in the tropics has shown that implementing the C\&I at the level of forest management units (FMUs) and using them to monitor performance of concessionaires can lead to significant improvements in forest management. It can also serve as a bridge to the voluntary certification of forest management by concessionaires [4,28,60]. Julve Larrubia et al. [35] and Wolfslehner et al. [22] observed that the willingness to apply C\&I for SFM locally is strong, but implementation is of varying quality. The use of C\&I is highly variable and scattered, and often only a few indicators are used. A major obstacle to the practical application of C\&I and the implementation of SFM on the ground is the complexity of the C\&I and the burden imposed by data collection, with the costs potentially exceeding the benefits. This finding emphasises the importance of coupling top-down regional and international C\&I initiatives with local bottom-up processes and allowing a gradient of C\&I implementation rather than prescribing rigid approaches.

Drivers for the increased local use of C\&I include a need for more consistent forest management planning and monitoring; requests for transparent, comprehensive objectives and the evaluation of progress towards these; the promotion of democratic elements, including public participation, through the use of C\&I, including in community forest management; the need for tools to secure access to funding and to increasingly globalized markets; and the need to comply with various standards, norms, and legal instruments [22]. In many countries where SFM is challenging, however, ensuring that C\&I support participation and transparency can be especially problematic. Key issues include the top-down approach to forest management at the heart of statutory laws, and a lack of capacity, which undermines implementation and may further alienate forest communities [57]. Such issues also apply to other aspects of forest management and policy; nevertheless, it is crucial that they inform the formulation and application of C\&I sets, which must be sufficiently flexible so that efforts can be scaled to match local capacities.

In contrast to C\&I, which are less developed at the local level than at the national, regional, and international level, forest management organizations use forest certification schemes to establish proof of SFM in FMUs. Such application may address some of the gaps in the local-level impact of C\&I on SFM.

Two forest certification systems dominate globally: the Forest Stewardship Council (FSC), and the Programme for the Endorsement of Forest Certification (PEFC). Both address the same issues of monitoring SFM as the regional and international C\&I processes but are focused exclusively at the FMU level and with a prescriptive intention to act as a voluntary market-based tool for promoting SFM. Certification schemes and C\&I processes were developed in parallel in the 1990s and learnt from each other. Indeed, the PEFC (then known as Pan-European Forest Certification) took at its starting point the pan-European operational-level guidelines of the Ministerial Conference on the Protection of Forests in Europe (which later became FOREST EUROPE), developed on the basis of the pan-European C\&I. The FSC, in contrast, developed its principles independently.

Both certification schemes have indicators in common with regional and international C\&I, with minor differences. The relatively small spatial scale and producer focus of certification, however, sets these schemes apart from the C\&I processes considered in this paper, which are considered at the national, regional or international spatial scales, encompassing different jurisdictions, management approaches, and forest goals. Still, certification has an important role in motivating the broad-scale adoption of SFM and related production techniques. It should be noted that 'forest area under a certification scheme' is viewed as an indicator of trends in SFM-for example, it is included in several regional and international indicator sets, and is also part of SDG indicator 15.2.1.

In 2017, 85\% of the total certified forest area worldwide-about 430 million hectares-was in North America, Europe, and the Commonwealth of Independent States [13] in the boreal and temperate climatic domains. Only $6.3 \%$ of permanent forests in the tropical domain have been certified to date [88]. Thus, forest certification covers only a small proportion of the total forest area, which might be considered an opportunity to increase the local-level implementation of C\&I, particularly in areas 
where the problems are most acute. The high cost of certification can pose a significant barrier to its adoption, particularly for smallholders in developing countries [61]. The application of C\&I can serve as a stepping stone towards certification by putting aspects of SFM in place, making it easier to obtain certification in the future.

\subsection{Impact on the Assessment of Progress towards SFM}

Indicators are usually developed based on existing data and information needs to report on the state of forests and forestry. While the quality and range of the available information has increased tremendously over the past 25 years, it is still challenging to state unambiguously whether a country's forests are sustainably managed or whether a country is making progress towards SFM or other global forest-related goals [14,89]. Part of this stems from a lack of relevant information, but even in the presence of an extensive information base, significant divergences in interpretation may still arise. This fact may be construed as a failing of C\&I frameworks, but it simply reinforces the observation that good information is necessary but not sufficient for SFM. In Southeast Asia, for example, the challenge starts with a lack of consistent basic forest data such as forest cover, this is further undermined by the political importance of the data itself (i.e., if forest area is increasing or decreasing) [90]. The issue is magnified by the lack of capacities and resources for the collection and dissemination of basic data revolving around SFM [91].

When, for instance, the pan-European C\&I were being negotiated, delegates were aware of the fact that the system under construction could not produce a single objective 'assessment' of the sustainability of forest management. Their response was that the system would generate information, and that it was upon users of the information, i.e., governments, NGOs, lobbyists, or journalists, to use it as they thought fit. [92]. Also, a missing clear link between C\&I and overarching SFM goals in a systematic way hampers such assessment [5]. Experience, notably with the SEMAFOR pilot study [13], seemed to show that (1) the C\&I system would have to be significantly redesigned to serve as an objective measure of overall sustainability; (2) that this redesign would be complex; and (3) that the political dimension to carry out this redesign is overly sensitive.

The future development of global, regional, international, and national indicators should focus on their suitability for the assessment of goals and targets-because the ability to monitor state behavior has become a critical tool of international governance. Kelly and Simmons [93] argue that the ability to implement assessment indicators constitutes an exercise of social power, with the potential to change important policy outputs at various levels.

Existing C\&I-based forest assessment procedures suffer from a lack of explicit objectives. Above all, however, with the partial exception of the ITTO C\&I, C\&I for SFM were designed to describe and monitor the sustainability of forest management but not to 'assess' it. Such assessment, although often mentioned in accompanying texts, would necessitate agreement on thresholds and an objective and quantifiable definition of what constitutes SFM at the national, local or FMU level. When most C\&I sets were being developed in the second half of the 1990s, no quantified goals had been agreed at the international level, and governments were unwilling to accept the introduction of thresholds for agreed indicators; they considered, rather, that this was a matter for sovereign nations to decide and that conditions varied too widely to allow uniform, internationally agreed thresholds. Targets or thresholds for individual indicators have only been developed, on a pilot basis, in SEMAFOR [13]; as part of the State of Europe's Forests Reports 2007 [62] and 2011 [23]; and in Austria's indicators for SFM [24]. Such thresholds are politically sensitive and difficult to homogenize at the global, regional, and international levels. Montréal Process countries generally use a narrative approach, highlighting key observations and areas of concern emerging from their indicators and discussing their implications for sustainability in a synthetic fashion (see, for example, [94]). New Zealand, a Montréal Process country, uses a hybrid approach in its latest report, combining a narrative analysis with judgements of indicator trends as positive, negative, or neutral [95]. In any case, strong political commitment is needed to support the assessment 
of SFM, which implies benchmarking and performance assessment. Although pilot approaches are being implemented the process is far from complete, and a systematic and widely accepted assessment methodology has not yet been developed. At the same time, many countries are gaining increasing experience in using C\&I frameworks to inform decision-makers and policy discussions about SFM by using indicator-based reports or deriving summary assessments or synthetic narrative approaches to address forest sustainability. The question of how to monitor progress towards globally, regionally or internationally agreed forest goals and objectives, and the link with C\&I, is still under discussion. Nevertheless, it is clear that the various sets of C\&I for SFM, and the processes behind their development, have drawn attention to the challenges, pointed to possible solutions, and identified technical and political difficulties to be avoided.

\subsection{Impact on Dialogue and Communication}

The impacts of regional and international C\&I processes on dialogue and communication signal that they have been instrumental in defining and specifying the content of SFM and making it more comprehensible. C\&I are widely recognized as suitable for defining an SFM framework that informs policy-makers and stakeholders and supports communication with the broader public $[5,15,53,96]$. They are perceived as a transparent means of communication for informing policies and decisions about the status of forests and forest management. Statements on assessments as to whether forests are sustainably managed or certain sustainability goals are reached are in demand $[8,16]$, but the concepts and their implementation still need considerable development. Currently, there is no strong consensus at the international policy level as to how and by whom overall sustainability of forest management should be assessed. Clarifying both parts of that question will be important to further develop C\&I sets in this direction (cf. Section 4.5).

Regional and international C\&I processes contributed to global negotiations on a non-legally binding instrument on forests, as well as to a possible legally binding agreement on forests in Europe, including by helping structure the agreements. C\&I processes also contributed to the determination of the UN's seven thematic elements of SFM and to the implementation of the SDGs. Nevertheless, there is a need and potential for further improvement of their communication function:

- The regional and international processes and the related sets of C\&I for SFM are complex and too focused on issues of interest only to the forest sector. This complexity hinders the communication of forest-related issues to the public and to other sectors because information embedded in the C\&I are difficult for many to comprehend.

- Most of the sets of C\&I for SFM are static. This limits the ad hoc consideration of emerging politically relevant issues (e.g., climate change, ecosystem services, and bioeconomy) and hampers dialogue between and compatibility with other C\&I processes. This is not an inherent shortcoming in the C\&I approach, pointing, rather, to the need for ongoing review and adjustment of C\&I frameworks. Such review and adjustment takes time and effort but is certainly possible -7 of the 11 regional and international C\&I processes have revised their C\&I at least once (and as many as four times) [15].

- In the last decade, the regional and international sets of C\&I for SFM have raised the attention and interest of other sectors in forest-related information, particularly in the climate-change, biodiversity and energy sectors. Challenges remain in improving consistency between the various areas of policy that influence, and are influenced by, forests and forest management. Regional and international sets of C\&I for SFM may help these sectors identify and incorporate new information by explicitly organizing available information and highlighting information deficiencies.

\section{Conclusions}

This study identified six domains in which, over the past 25 years, intergovernmental, regional, and international C\&I processes have had positive impacts on the comprehension and implementation 
of SFM. Their C\&I for SFM have: (1) enhanced the discourse and understanding of SFM; (2) helped shape and focus the engagement of science in SFM; (3) improved monitoring and reporting on SFM to facilitate transparency and evidence-based decision-making; (4) strengthened forest management practices; (5) initiated assessment of progress towards SFM goals, but still incomplete; and (6) improved forest-related dialogue and communication in and outside the forest sector, but still strongly limited to sectoral boundaries.

Thus, regional and international sets of C\&I for SFM provide a vital structure for monitoring, assessing, and reporting on forests and their management and fostering progress towards sustainability goals. Moreover, the success of intergovernmental regional and international C\&I processes can be linked to several unique features of the framework and the processes that maintain them. Namely, C\&I are holistic and provide a comprehensive picture of all aspects of SFM. They are adaptable to different scales, applied from the local to the global level, and have led to the development of reporting mechanisms that fulfil the needs of countries. Furthermore, C\&I processes are often highly participatory, involving many groups of stakeholders and providing a vital network to foster collaboration and support. Notably, C\&I provide a common language that is consistent, credible, relevant, and usable. The further strengthening and promotion of these features by the organizations and member countries of the C\&I processes in cooperation with international organizations will help increase the impacts of C\&I in the future.

We have demonstrated various ways that C\&I for SFM have had significant impacts in the last 25 years and advanced approaches towards providing a harmonized framework and demonstration of SFM. While the monitoring and data aspects are progressing, the issue of sustainability assessment will require further scrutiny, particularly in regard to the discrepancies between politics and science advances. Taking the next steps in development will involve surmounting a range of technical and social challenges. Paramount among the technical challenges will be to develop analytical approaches for showing progress towards SFM. The indicator sets reflect a complex system and require a mix of qualitative and quantitative data. New experimental methodologies such as SEMAFOR are providing insights into possible ways forward. Among the social challenges is ensuring that C\&I processes move forward in tandem with other international indicator-using initiatives, such as the SDGs, and developing initiatives in other sectors.

With continued commitment by countries, intergovernmental bodies and fora, we see opportunities for further impacts on global forest policy statements, national forest strategies, development plans, and other policy instruments to strengthen progress toward SFM in all forest types and all countries. The issue of an overall SFM assessment will require particularly further political commitment.

Finally, C\&I constitute a powerful policy tool for generating understandable information that provides evidence of the effectiveness of policy measures and management practices. C\&I for SFM-based reports have proven their value in addressing pressing forest-related issues, such as the need to develop sustainable bio-based economies, maintain and protect biodiversity, or mitigate and adapt to climate change. The successes and lessons learned from forestry can and should be carried over to other sectors to advance sustainability goals more broadly.

Author Contributions: Conceptualization, S.L. and B.W.; Methodology, S.L.; Questionnaire Input: S.L., D.G., S.J., and G.R.; Writing-Original Draft Preparation, S.L., B.W., S.R.J.B., D.G., S.J., T.P., K.P., R.R., and G.R.; Writing-Review \& Editing, S.L., B.W., S.R.J.B., D.G., S.J., T.P., K.P., R.R., and G.R.; Visualization, S.L.

Funding: This research received no external funding.

Acknowledgments: The authors kindly thank Pablo Laclau, Vicente Guadalupe, Karl Hogl, and two anonymous reviewers for their constructive comments and suggestions to improve the quality of the paper.

Conflicts of Interest: The authors declare no conflict of interest. 


\section{Abbreviations}

$\begin{array}{ll}\text { ACTO } & \text { Amazon Cooperation Treaty Organization } \\ \text { ASEAN } & \text { Association of Southeast Asian Nations } \\ \text { ATO } & \text { African Timber Organization } \\ \text { C\&I } & \text { Criteria and Indicators } \\ \text { CBD } & \text { Convention on Biological Diversity } \\ \text { CFRQ } & \text { Collaborative Forest Resources Questionnaire } \\ \text { CITES } & \text { Convention on International Trade in Endangered Species of Wild Fauna and Flora } \\ \text { EFI } & \text { European Forest Institute } \\ \text { FAO } & \text { Food and Agriculture Organization of the United Nations } \\ \text { FMU } & \text { Forest management unit } \\ \text { FRA } & \text { Forest Resource Assessment of the FAO } \\ \text { FSC } & \text { Forest Stewardship Council } \\ \text { ITTO } & \text { International Tropical Timber Organization } \\ \text { IUFRO } & \text { International Union of Forest Research Organizations } \\ \text { NENA } & \text { Near East and North Africa } \\ \text { NGO } & \text { Non-governmental organization } \\ \text { NLBI } & \text { Non-Legally Binding Instrument } \\ \text { PEFC } & \text { Programme for the Endorsement of Forest Certification } \\ \text { SDG } & \text { Sustainable Development Goal } \\ \text { SEMAFOR } & \text { System for the Evaluation of the Management of Forests } \\ \text { SFM } & \text { Sustainable Forest Management } \\ \text { UN } & \text { United Nations } \\ \text { UNCCD } & \text { United Nations Convention to Combat Desertification } \\ \text { UNCED } & \text { United Nations Conference on Environment and Development } \\ \text { UNECE } & \text { United Nations Economic Commission for Europe } \\ \text { UNFCCC } & \text { United Nations Framework Convention on Climate Change } \\ & \end{array}$

\section{References and Notes}

1. General Assembly 2007: Non-Legally Binding Instrument on All Types of Forests (A/RES/62/98); United Nations: Bali, Indonesia, 2008.

2. Criteria and Indicators for Sustainable Forest Management. Available online: http://www.fao.org/forestry/ ci/88506/en/ (accessed on 7 March 2018).

3. Davis, K.; Kingsbury, B.; Merry, S. Indicators as a technology of global governance. Law Soc. Rev. 2012, 46, 71-104. [CrossRef]

4. Caswell, S.; Tomaselli, I.; Hirakuri, S. Indicating Progress: Uses and Impacts of Criteria and Indicators for Sustainable Forest Management; ITTO Technical Series No. 42; ITTO: Yokohama, Japan, 2014; ISBN 978-4-86507-010-1.

5. Baycheva, T.; Inhaizer, H.; Lier, M.; Prins, K.; Wolfslehner, B. Implementing Criteria and Indicators for Sustainable Forest Management in Europe; European Forest Institute: Joensuu, Finland, 2013; ISBN 978-952-5980-04-2.

6. Lammerts van Bueren, E.; Blom, E. Hierarchical Framework for the Formulation of Sustainable Forest Management Standards; Backhuys: Leiden, The Netherlands, 1997.

7. Linser, S. Critical Analysis of The Basics for The Assessment of Sustainable Development by Indicators; Fortswissenschaftliche Fakultät der Universität Freiburg: Breisgau, Germany, 2002; ISBN 3-933548-17-9.

8. Linser, S.; Wolfslehner, B. Report on the Mid-Term Evaluation: Meeting the Goals for European Forests and the European 2020 Targets for Forests; Forest Europe Liaison Unit: Madrid, Spain, 2015.

9. Linser, S. Background Information on Subsets of pan-European Indicators for SFM to address specific policy issues. In Proceedings of the 1st Meeting of the Expert Group on Implementation of the Updated pan-European Indicators for SFM, Zvolen, Slovakia, 24-25 January 2017.

10. McCool, S.; Stankey, G. Representing the future: A framework for evaluating the utility of indicators in the search for sustainable forest management. In Criteria and Indicators for Sustainable Forest Management; Raison, R., Brown, A., Flinn, D., Eds.; CAB International: Wallingford, UK, 2001; ISBN 978-0851993928. 
11. Mendoza, G.; Prabhu, R. Fuzzy methods for assessing criteria and indicators of sustainable forest management. Ecol. Indic. 2003, 3, 227-236. [CrossRef]

12. Siry, J.; Cubbage, F.; Ahmed, M. Sustainable forest management: Global trends and opportunities. For. Policy Econ. 2005, 7, 551-561. [CrossRef]

13. UNECE. Pilot Project on the System for the Evaluation of the Management of Forests (SEMAFOR); Geneva Timber and Forest Discussion Paper 66; United Nations: Geneva, Switzerland, 2017.

14. Wolfslehner, B.; Linser, S.; Pülzl, H.; Bastrup-Birk, A.; Camia, A.; Marchetti, M. Forest bioeconomy-A new scope for sustainability indicators. In From Science to Policy; European Forest Institute: Joensuu, Finland, 2016; Volume 4, ISBN 978-952-5980-29-5.

15. Linser, S.; Wolfslehner, B.; Asmar, F.; Bridge, S.R.; Guadalupe, V.; Gritten, D.; Jafari, M.; Johnson, S.; Laclau, P.; Robertson, G. 25 years of criteria and indicators for sustainable forest management: Why some intergovernmental C\&I processes flourished while others faded. Forests 2018, 9, 515. [CrossRef]

16. FAO. Keeping an Eye on SDG 15-Working with Countries to Measure Indicators for Forests and Mountains. Available online: http:/ / www.fao.org/3/a-i7334e.pdf (accessed on 1 June 2018).

17. Natural Resources Canada; FAO. Proceedings of the International Expert Workshop on Strengthening Collaboration on Criteria and Indicators to Promote and Demonstrate Sustainable Forest Management, Ottawa, ON, Canada, 1-3 May 2016; FAO: Rome, Italy, 2016; Available online: http:/ / www.fao.org/forestry /45401051b882b24060ae2a238aed3c6cda3b70.pdf (accessed on 1 June 2018).

18. Harisson, C. Mail Surveys and Paper Questionnaires. In Handbook of Survey Research; Emerald: Bingley, UK, 2010; ISBN 978-1-84855-224-1.

19. Dillman, D.A.; Messer, B.L. Mixed-Mode Surveys. In Handbook of Survey Research; Emerald: Bingley, UK, 2010; ISBN 978-1-84855-224-1.

20. United Nations. Earth Summit Agenda 21. The United Nations Program of Action from Rio; United Nations: Bali, Indonesia, 1992; Available online: https://sustainabledevelopment.un.org/content/dsd/agenda21/ index.shtml (accessed on June 1992).

21. Forest Europe. The pan-European policies and tools for sustainable forest management. In Forest Europe Policy Brief; Forest Europe Liaison Unit: Oslo, Norway, 2011.

22. Wolfslehner, B.; Linser, S.; Julve Larrubia, C.; Rametsteiner, E. Using Criteria and Indicators for SFM to Promote and Provide Incentives for the Transition to Sustainable Forestry Practices; FAO Working Paper; FAO: Rome, Italy, 2018; under review.

23. Forest Europe; UNECE; FAO. State of Europe's Forests 2011; Status and Trends in Sustainable Forest Management in Europe; Forest Europe Liaison Unit: Oslo, Norway, 2011; ISBN 978-82-92980-05-7.

24. Linser, S. ÖWAD-Indikatorenset für Nachhaltige Waldbewirtschaftung; BMLFUW: Vienna, Austria, 2017.

25. Sarre, A.; Sabogal, C. Is SFM an impossible dream? Unasylva 2013, 240, 29-34.

26. Baycheva-Merger, T.; Wolfslehner, B. Evaluating the implementation of the Pan-European Criteria and indicators for sustainable forest management-A SWOT analysis. Ecol. Indic. 2016, 60, 1192-1199. [CrossRef]

27. Elgert, L. Global governance and sustainability indicators: The politics of expert knowledge. In Handbook of Critical Policy Studies; Fischer, F., Torgerson, D., Duranova, A., Orsini, M., Eds.; Edward Elgar: Cheltenham, UK, 2016; pp. 341-357.

28. Caswell, S. The impacts of criteria and indicators. Trop. For. Updat. 2014, 22, 3-10.

29. Grainger, A. Forest sustainability indicator systems as procedural policy tools in global environmental governance. J. Glob. Environ. Chang. 2012, 22, 147-160. [CrossRef]

30. Pokorny, B.; Adams, M. What do criteria and indicators assess? An analysis of five C\&I sets relevant for forest management in the Brazilian Amazon. Int. For. Rev. 2003, 5, $20-28$.

31. Wijewardana, D. Criteria and indicators for sustainable forest management: The road travelled and the way ahead. Ecol. Ind. 2008, 8, 115-122. [CrossRef]

32. Natural Resources Canada. Proceedings of the Joint Workshop to Streamline Global Forest Reporting and Strengthen Collaboration among International Criteria and Indicator Processes; Natural Resources Canada: Victoria, BC, Canada, 2012; Available online: https:/ / cfs.nrcan.gc.ca/publications/download-pdf/33398 (accessed on 1 June 2018).

33. Roux, D.J.; Rogers, K.H.; Biggs, H.C.; Ashton, P.J.; Sergeant, A. Bridging the science-management divide: Moving from unidirectional knowledge transfer to knowledge interfacing and sharing. Ecol. Soc. 2006, 11, 4. [CrossRef] 
34. International Tropical Timber Organization (ITTO). Criteria and Indicators for the Sustainable Management of Tropical Forests; ITTO Policy Development Series 21; ITTO: Yokohama, Japan, 2016; ISBN 978-4-86507-028-6.

35. Julve Larrubia, C.; Ross, K.; Wolfslehner, B.; Guldin, R.; Rametsteiner, E. Using Criteria and Indicators for Sustainable Forest Management. A Way to Strengthen Results-Based Management of National Forest Programmes; FAO Forestry Policy and Institutions Working Paper 37; FAO: Rome, Italy, 2017.

36. Canadian Council of Forest Ministers. Measuring Our Progress: Putting SFM into Practice across Canada and Beyond; Canadian Council of Forest Ministers: Ottawa, ON, Canada, 2008.

37. Hock, B. Value-driven sustainable forest management in New Zealand. Int. J. Environ. Sustain. 2013, 8, 71-85. [CrossRef]

38. Payn, T.W.; Barnard, T.D.; Cox, S.; Millard, L.; Novis, J.; Reid, A. Sustainable Forest Management Developments in New Zealand Seen through the Lens of the Montréal Process Criteria and Indicators (CEI) Framework; XIV World Forestry Congress: Durban, South Africa, 2015.

39. Singh, R.K.; Murty, H.R.; Gupta, S.K.; Dikshit, A.K. An overview of sustainability assessment methodologies. Ecol. Ind. 2009, 9, 189-212. [CrossRef]

40. Wolfslehner, B.; Vacik, H. Mapping indicator models: From intuitive problem structuring to quantified decision-making in sustainable forest management. Ecol. Ind. 2011, 11, 274-283. [CrossRef]

41. UNCED. Non-Legally Binding Authoritative Statement of Principles for a Global Consensus on the Management, Conservation and Sustainable Development of All Types of Forests; Report of the United Nations Conference on Environment and Development (A/CONF.151/26). Available online: http: / / www.un.org/documents/ga/conf151/aconf15126-1 (accessed on June 1992).

42. MacDicken, K.; Sola, P.; Hall, J.; Sabogal, C. Global progress toward sustainable forest management. For. Ecol. Manag. 2015, 352, 47-56. [CrossRef]

43. Prins, K. Synergies between forest resources assessment and indicators of sustainable forest management: The European experience. Unasylva 2002, 210, 65-73.

44. FAO. Report of the International Conference on the Contribution of Criteria and Indicators for Sustainable Forest Management: The Way Forward (CICI-2003); FAO: Guatemala City, Guatemala, 2003.

45. FAO. Report of the FAO/ITTO Expert Consultation on Criteria and Indicators for Sustainable Forest Management; FAO: Cebu City, Philippines, 2004.

46. MCPFE. Inter-Criteria and Indicators Process Collaboration Workshop Report; A Collaborative Effort by the ITTO, the MCPFE, the Montreal Process, the FAO, the UNECE and the U.S. Forest Service; MCPFE: Warsaw, Poland, 2007.

47. USDA Forest Service. Conference Proceedings: Forest Criteria and Indicators Analytical Framework and Report Workshop, Joensuu, Finland, 19-21 May 2008; General Technical Report GTR-WO-81; USDA Forest Service: Washington, DC, USA, 2009.

48. Goto, T.; Sarsito, A. Co-chairs' Summary Report. In Proceedings of the International Seminar on Challenges of Sustainable Forest Management-Integrating Environmental, Social, and Economic Values of Forests, Tokyo, Japan, 8-9 March 2011.

49. Adam, M.C.; Kneeshaw, D. Local level criteria and indicator frameworks: A tool used to assess aboriginal forest ecosystem values. For. Ecol. Manag. 2008, 255, 2024-2037. [CrossRef]

50. Chirici, G.; McRoberts, R.; Winter, S.; Marchetti, M. National Forest Inventory Contributions to Forest Biodiversity Monitoring. For. Sci. 2012, 58, 257-268. [CrossRef]

51. United Nations. Contribution of the Collaborative Partnership on Forests and its members, regional and subregional organizations and processes, major groups and other stakeholders to the implementation of the United Nations strategic plan for forests 2017-2030. Note by the UNFF Secretariat. In E/CN.18/2018/3; United Nations: New York, NY, USA, 2018.

52. Guadalupe, V.; (ACTO Secretariat, Brasilia, Brazil). Personal communication, 2018.

53. Forest Europe. Report on Future Direction of Forest Europe. Part I: Results of the Questionnaire Survey; Forest Europe Liaison Unit: Bratislava, Slovakia, 2017.

54. FAO. Strengthening Evidence-Based Forest Policy-Making. Linking Forest Monitoring with National Forest Programmes; Forestry Policy and Institutions Working Paper 33; FAO: Rome, Italy, 2014.

55. FAO. Use of Sustainability Indicators in Forest Policy and Practice in Southeast Asia: Experiences, Lessons Learned, Needs and Potential for Further Development of Indicators for Enhanced Use; FAO: Bangkok, Thailand, 2015. 
56. Sikor, T.; Gritten, D.; Atkinson, J.; Bao, H.; Dahal, G.; Duangsathaporn, K.; Hurahura, F.; Marona, S.; Maryudi, A.; Phanvilay, K.; et al. Community Forestry in Asia and the Pacific: Pathway to Inclusive Development; RECOFTC: Bangkok, Thailand, 2013.

57. Gritten, D.; Greijmans, M.; Lewis, S.; Atkinson, J.; Tol, S.; Tan, N.; Poudyal, B.; Bampton, J. An Uneven Playing Field: Regulatory barriers to communities making a living from the timber from their forests-Examples from Cambodia, Nepal, Vietnam. Forests 2015, 6, 3433-3451. [CrossRef]

58. Ahimin, O.; Mikissa, J.B.; Johnson, S.; N’Guessan Kouamé, F.; Kamanzi, K. Implementing Principles, Criteria and Indicators for Sustainable Forest Management in Gabon. J. Sustain. For. 2018, 37, 1-8. [CrossRef]

59. Boscolo, M.; Snook, L.; Quevedo, L. Adoption of sustainable forest management practices in Bolivian timber concessions: A quantitative assessment. Int. For. Rev. 2009, 11, 514-523. [CrossRef]

60. Ahimin, O. Africa's process for implementing PC\&I. Trop. For. Updat. 2014, 22, 11-14.

61. McDermott, C.; Irland, L.; Pacheco, P. Forest certification and legality initiatives in the Brazilian Amazon: Lessons for effective and equitable forest governance. For. Policy Econ. 2015, 50, 134-142. [CrossRef]

62. Forest Europe. State of Europe's Forests 2007; The MCPFE Report on Sustainable Forest Management in Europe; Forest Europe Liaison Unit: Warsaw, Poland, 2007; ISBN 978-83-922396-8-0.

63. International Tropical Timber Organization (ITTO). Status of Tropical Forest Management 2005; ITTO Technical Series No. 24; ITTO: Yokohama, Japan, 2006; ISBN 4-902045-24-9.

64. Blaser, J.; Sarre, A.; Poore, D.; Johnson, S. Status of Tropical Forest Management 2011; ITTO Technical Series No. 38; ITTO: Yokohama, Japan, 2011.

65. Shields, D.; Šolar, S.; Martin, W. The role of values and objectives in communicating indicators of sustainability. Ecol. Ind. 2002, 2, 149-160. [CrossRef]

66. Solesbury, W. Evidence Based Policy: Whence It Came and Where It's Going; Working Paper 1; ESRC; UK Centre for Evidence Based Policy and Practice: London, UK, 2001.

67. Collins, H.; Evans, B. Rethinking Expertise; The University of Chicago Press: Chicago, IL, USA; London, UK, 2007.

68. Gardner, S. Developing Environmental Evidence-Based Policies. Available online: file:///M:/IUFRO\% 20WP/Literatur /Gardner_2009_\%20Developing\%20environmental\%20evidence-based\%20policies.html (accessed on 30 July 2018).

69. Leshner, A. Science and Sustainability. Science 2002, 297, 897. [CrossRef] [PubMed]

70. Prabhu, R.; Ruitenbeek, H.; Boyle, T.; Colfer, C. Between voodoo science and adaptive management: The role and research need of indicators for SFM. In Criteria and Indicators for Sustainable Forest Management; Raison, R., Brown, A., Flinn, D., Eds.; CAB International: Wallingford, UK, 2001.

71. McDonald, G.T.; Lane, M.B. Converging global indicators for sustainable forest management. For. Policy Econ. 2004, 6, 63-70. [CrossRef]

72. FAO. Expert Workshop on Strengthening Collaboration on Criteria and Indicators to Promote and Demonstrate Sustainable Forest Management; FAO: Ottawa, ON, Canada, 2016.

73. Forest Europe. Valuation of Forest Ecosystem Services, Final Report; Group of Expert (2012-2014) \& Belgrade Workshop; 24-25 September 2014 in Serbia; Ministerial Conference on the Protection of Forests in Europe; Forest Europe Liaison Unit: Madrid, Spain, 2014.

74. Rametsteiner, E.; Simula, M. Forest certification—An Instrument to Promote Sustainable Forest Management? J. Environ. Manag. 2003, 67, 87-98. [CrossRef]

75. Payn, T.; (Scion, Rotorua, New Zealand). Personal communication, 2018.

76. Forest Europe. State of Europe's Forests 2015; Forest Europe Liaison Unit: Madrid, Spain, 2015.

77. UNECE. Forests in the ECE Region: Trends and Challenges in Achieving the Global Objectives on Forests. In ECE/TIM/SP/37; United Nations: Bali, Indonesia, 2015.

78. Rametsteiner, E.; Pülzl, H.; Alkan-Olsson, J.; Frederiksen, P. Sustainability indicator development—Science or political negotiation? Ecol. Ind. 2011, 11, 61-70. [CrossRef]

79. Dahl, A. Achievements and gaps in indicators for sustainability. Ecol. Ind. 2012, 17, 14-19. [CrossRef]

80. Gritten, D.; (RECOFT, Bangkok, Thailand). Personal communication, 2018.

81. FAO. FRA 2020. In Guidelines and Specifications; Version 1.0.; FAO: Rome, Italy, 2018.

82. McGinley, K.A.; Cubbage, F.W. Examining Forest Governance in the United States through the Montréal Process Criteria and Indicators Framework. Int. For. Rev. 2017, 19, 192-208. [CrossRef] 
83. Program on Forests (PROFOR) Kishor Nalin and Kenneth Rosenbaum. In Assessing and Monitoring Forest Governance: A User's Guide to a Diagnostic Tool; Program on Forests (PROFOR); World Bank: Washington, DC, USA, 2012; ISBN 978-0-9855195-2-0.

84. Montréal Process. Criteria and Indicators for the Conservation and Sustainable Management of Temperate and Boreal Forests, 5th ed.; Montréal Process Liaison Office: Rotorua, New Zealand, 2015; Available online: https: / / montrealprocess.org/documents/publications/techreports/MontrealProcessSeptember2015.pdf (accessed on 1 June 2018).

85. OTCA/OIMT. Criterios e Indicadores de Sostenibilidad del Bosque Amazónico. Policy Development Report for ITTO; unpublished; ITTO: Yokohama, Japan, 2014.

86. Jafari, M. Tehran process and C\&I for SFM in LFCCs and near east dry land zones. In Proceedings of the International Seminar on Challenges of Sustainable Forest Management, Integrating Environmental, Social and Economic Values of Forests, Tokyo, Japan, 8-10 March 2011.

87. Bosela, M.; Larocque, G.; Baycheva, T.; Valbuena, R.; Lier, M. Criteria and Indicators of Sustainable Forest Management. In Ecological Forest Management Handbook; Larocque, G., Ed.; CRC Press: Boca Raton, FL, USA, 2015; pp. 384-413.

88. Hontelez, J.; (FSC Secretariat, Brussels, Belgium). Personal communication, 2018.

89. Prins, K. Monitoring progress towards sustainable forest management, through a set of indicators or an index: Some suggestions. In Proceedings of the 2nd Informal Inter-agency Meeting on Indicators to Monitor Progress towards SFM and Forest-Related SDG Indicators, New York, NY, USA, 29 April 2016; CPF: New York, NY, USA, 2016.

90. Riggs, R.A.; Langston, J.D.; Sayer, J. Incorporating governance into forest transition frameworks to understand and influence Cambodia's forest landscapes. For. Policy Econ. 2018, 96, 19-27. [CrossRef]

91. ESCAP. Asia and the Pacific SDG Progress Report 2017; The Economic and Social Commission for Asia and the Pacific (ESCAP): Bangkok, Thailand, 2018.

92. Prins, K.; (Carouge, Switzerland). Personal communication, 2018.

93. Kelly, J.G.; Simmons, B.A. Politics by Number: Indicators as Social Pressure in International Relations. Am. J. Political Sci. 2015, 59, 55-71. [CrossRef]

94. USDA Forest Service. National Report on Sustainable Forests-2010; Robertson, G., Ed.; Chief. FS-979; USDA Forest Service: Washington, DC, USA, 2011.

95. New Zealand Ministry for Primary Industries. Sustainable Management of New Zealand's Forests: New Zealand's Third Country Report on the Montréal Process Criteria and Indicators; New Zealand Ministry for Primary Industries: Wellington, New Zealand, 2015.

96. FAO Website on Global Forest Resources Assessments. Available online: http://www.fao.org/forestresources-assessment/current-assessment/en/ (accessed on 30 July 2018). 